\title{
policy statements and statements of concern of the AMS
}

The purpose of these statements will be to give guidance to the public on what can (and cannot) be provided by the meteorological profession at the present state of advance of the science, to urge appropriate action in pending matters of public policy that are of concern to atmospheric science, or to address the meteorological profession on matters that require urgent attention.

\section{Currently Approved Statements}

Statement on Weather Radar (January 18, 1981), Bulletin, May 1981, p. 678. The Council on January 9, 1984, voted to extend the life of this Statement for three years.

Statement on Weather Satellite Operation by Private Industry (April 28, 1983), Bulletin, August 1983, p. 975.

Statement on Weather Forecasting (September 29, 1983), Bulletin, December 1983, p. 1385.

The Atmospheric Environment: An Agenda for Action; A Statement of the American Meteorological Society (September 29, 1983). Bulletin, January 1984, p. 60.

A Statement of the Council on the Atmospheric Consequences of Nuclear Warfare (September 30, 1983), Bulletin, March 1984, p. 242.

A Statement of the Council on an Independent Federal Agency for the Atmosphere and the Oceans (September 30, 1983), Bulletin, March 1984, p. 242.

Statement on Planned and Inadvertent Weather Modification (September 27, 1984), BulletiN, April 1985, p. 447.

Statement on Mobile Homes and Severe Windstorms (January 6, 1985), Bulletin, July 1985, p. 857.

Flash Floods; A Statement of Concern by The American Meteorological Society (January 6, 1985), Bulletin, July 1985, p. 858.

Statement on Tornado Detection, Forecasting, Warning, and Tracking (August 20, 1985), BulletiN, August 1985, p. 1040

An official statement of the American Meteorological Society is one that has received council approval, or, in a situation that the Executive Committee defines as an emergency, approval by the Committee on Public Policy (COMPUP). Guidance in the preparation of such statements has recently been provided by the council (see Bulletin, May 1974, p. 439, and also an earlier policy statement in BULLETIN, July 1963, p. 446).

An official statement on a technical subject (such as weather forecasting, weather modification, etc.) will automatically be withdrawn and no longer listed in the BuLLETIN three years from its date of publication in the BulletiN, unless the cognizant committee recommends to the council that its life be extended for another three years in either its present or amended form, and the council so approves. An official statement on a special topic, contained, for example, in a letter from the AMS president or in testimony before Congress of an official of the AMS on a matter of government or public policy, is usually directed at a specific matter of current concern and therefore may not be noteworthy for more than a year. Such topical statements will be reviewed annually by the Executive Committee and withdrawn or extended by it as deemed appropriate. 